\title{
SHRIMP zircon U-Pb dating of the mafic and felsic intrusive rocks of the Saza area in the Lupa goldfields, southwestern Tanzania: Implication for gold mineralization
}

\author{
Shukrani Manya \\ Department of Geology, University of Dar es Salaam, Dar es Salaam, Tanzania; shukrani73@udsm.ac.tz, shukrani73@yahoo.com
}

Received 5 July 2012; revised 10 August 2012; accepted 17 August 2012

\section{ABSTRACT}

The Lupa Goldfield (LGF) is one of the eight structural terranes in the NW-SE striking Ubendian Belt of SW Tanzania. The LGF is comprised of granitic gneisses with bands of amphibolites which are intruded by mafic intrusions including gabbros, granodiorites, diorites; and various granites as well as metavolcanics. These rocks are cross-cut by narrow mafic dykes and aplites. SHRIMP zircon U-Pb data are presented for the granodiorite and a mafic dyke that cross-cut the granodiorites in the Saza area of the LGF, with the aim of constraining the mafic and felsic magmatism and their implication to gold mineralization. The zircon U-Pb data shows that the Saza granodiorites were emplaced at $1924 \pm 13$ Ma (MSWD = 2.6) whereas the cross-cutting mafic dyke yielded a zircon U-Pb age of $1758 \pm$ $33 \mathrm{Ma}$ (MSWD $=0.88$ ). The dated granodiorite sample was in sheared contact with an altered mafic intrusive rock, most likely a diorite, along which an auriferous quartz vein occurs. The $1924 \pm 13 \mathrm{Ma}$ age of granodiorites is within error of the reported molybdenite Re-Os age of 1937 Ma determined for the gold mineralization event in Lupa goldfields. Although auriferous quartz veins are younger than the granodiorites, the more or less similar ages between the emplacement of granodiorites and the mineralizing event indicate that the granodiorites might be the heat source (or driver) of hydrothermal fluids responsible for gold mineralization in the Lupa goldfields. This would further suggest that gold mineralization in the LGF is intrusion-related type. The mafic dykes represent the youngest rocks to have been emplaced in the area and hence the $1758 \pm 33 \mathrm{Ma}$ age of the mafic dykes conclude the magmatic evolution in the Lupa goldfields during the Palaeoproterozoic.

Keywords: Lupa Goldfields; Saza; SHRIMP Zircon U-Pb Dating; Palaeoproterozoic; Gold

Mineralization

\section{INTRODUCTION}

The NW-SE Ubendian Belt of SW Tanzania is bordered by the Tanzania Craton to the northeast and the Bangweulu Block to the southwest (Figure 1). The Ubendian Belt consists of high-grade metamorphic rocks of sedimentary and igneous origin, including granulites, migmatite, amphibolites, biotite gneisses, schists, quartzites, eclogites and marble. Granites are the main type of intrusive rocks, but there are also granodiorites, diorites, gabbro and carbonatite rocks [1]. The Belt has been subdivided, on the basis of structural and lithological differences into 8 blocks (or terranes) namely: Ubende, Wakole, Katuma, Ufipa, Upangwa, Nyika, Mbozi and Lupa [2,3] (Figure 1). The Ubende, Wakole and Katuma terranes are the northwesterly of the eight whereas the Ufipa, Mbozi, Upangwa, Nyika and Lupa are on the southeast.

The Ubende terrane is dominated by amphibolites and amphibole gneisses which also host mylonitic eclogites. Boniface et al. [4]. showed that the Ubende eclogites show a MORB-like chemistry and yielded SHRIMP zircon U-Pb ages of $1886 \pm 16$ and $1866 \pm 14$ Ma suggesting the existence of a Palaeoproterozoic ocean floor subduction in the Ubendian Belt. The Ufipa terrane is mainly composed of granitic biotite gneisses, hornbelende gneisses and granet-kyanite gneisses. These gneisses host lenses of kyanite-free and kyanite-bearing eclogites whose chemistry is similar to back-arc basin basalts and yielded SHRIMP zircon U-Pb ages of $593 \pm$ $20 \mathrm{Ma}$ and $524 \pm 6 \mathrm{Ma}$. This led Boniface et al. [4] to 


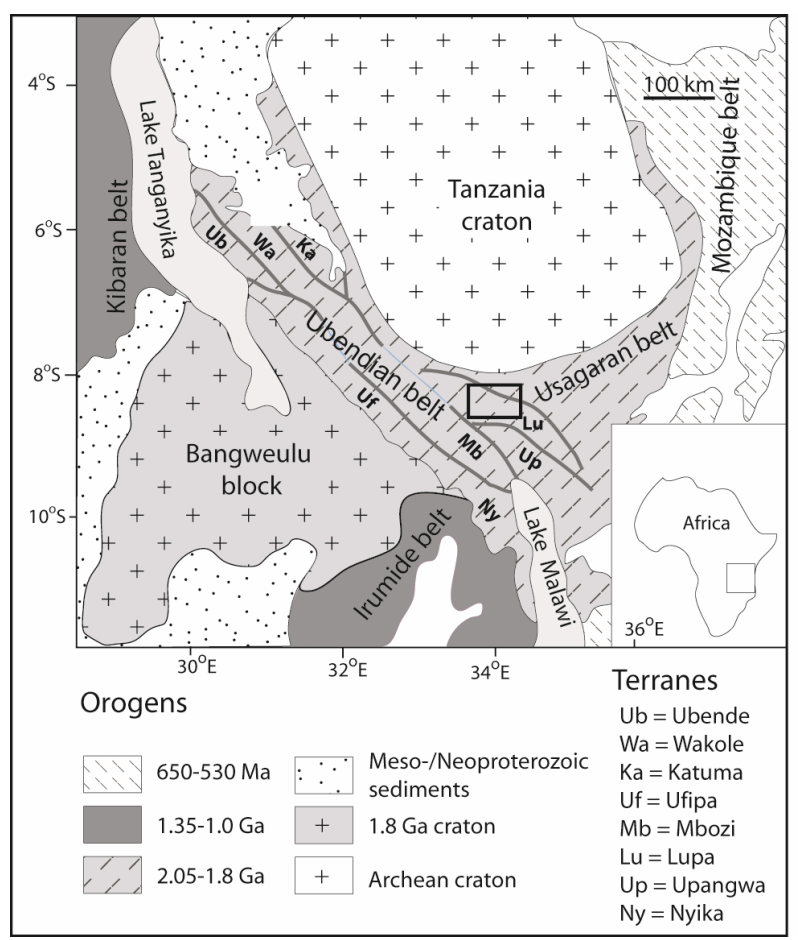

Figure 1. Geological map of south-eastern Africa indicating the location of the Ubendian Belt and its subdivision into eight structural and lithological terranes, modified after Hanson [5]. The position shown by a frame box is part of the Lupa block which is the study area in Figure 2.

suggest the existence of Neoproterozoic convergent margin in the Ubendian Belt. Dominant lithologies in other terranes include alumino-silicate schists for Wakole, migmatitic biotite gneisses (Katuma), mafic granulites and syenites (Mbozi), meta-anorthosites (Upangwa), and cordierite gneisses (Nyika).

The Lupa terrane (part of which is the subject of this study) is dominated by granitic gneisses with amphibolitic bands and are intruded by mafic intrusions including gabbros, granodiorites, diorites; and various granites [6]. Metavolcanics are predominantly felsic and occur in the Ngualla area. Mnali [6] reported zircon $\mathrm{U}-\mathrm{Pb}$ ages of $1937 \pm 47 \mathrm{Ma}(\mathrm{MSWD}=230)$ for the Saza-Chunya granodiorite and $1931 \pm 44$ Ma (MSWD = 110) for the Ilunga granite and proposed that both types of granitoids were emplaced at between 1920 and 1960 Ma. Note the large MSWD values associated with the reported ages.

The Ubendian Belt hosts polymetallic gold and base metal deposits in the Mpanda Mineral Field (MMF) where gold occurs associated with lead, copper and zinc mineralization [7]. Gold has been recovered as a byproduct of $\mathrm{Cu}$ and $\mathrm{Pb}$ mining (e.g. at MukwambaNyakaliza prospect). On the other hand, gold rather than polymetallic $\mathrm{Pb}-\mathrm{Zn}-\mathrm{Au}-\mathrm{Ag}$ typical association of MMF is found in the LGF [6]. In both the LGF and MMF, the mineralization is restricted to the sulphide-bearing quartz veins in major shear zones and the link between the gold mineralization event and the emplacement of felsic intrusions remain inconclusive [8].

This paper presents the SHRIMP zircon U-Pb ages for the Saza granodiorite and a mafic dyke with the aim of better constraining the emplacement ages of the mafic and felsic igneous intrusion events in the Saza area of the LGF and their implication to gold mineralization. It is shown that the Saza granodiorite was emplaced at $1924 \pm$ $13 \mathrm{Ma}$, an age that is within error of the reported gold mineralization Re-Os age of 1937 Ma which suggests that the granodiorites might be the heat source of hydrothermal fluids responsible for gold mineralization in the Lupa goldfields. The data also shows that the mafic dykes cross-cutting the granodiorites were emplaced at $1758 \pm 33 \mathrm{Ma}$ and this concludes the magmatic evolution of the Lupa Goldfields during the Palaeoproterozoic.

\section{GEOLOGICAL BACKGROUND}

The geology of the Saza area in the LGF is best described by Mnali [6]. The Saza area is located on the eastern margin of the LGF and forms part of the exploration license of Helio Resources Corp (Figure 2). The area is comprised of granitic gneisses which are intruded by a body of mafic rocks including gabbros, diorites, granodiorites, and granites (locally known as Ilunga granites). According to Mnali [6], the gabbros and diorites are in gradational contact with granodiorites and the granodiorites do not show any obvious contact with the Ilunga granites.

Mnali [6] reported a U-Pb bracket age of 1920-1960 Ma for emplacement of both the Saza granodiorite and Ilunga granite. The Ilunga granites are spatially associated with minor felsic volcanic rocks whose age is unknown. The granodiorites are comprised of mafic xenoliths which points to the presence of an earlier mafic magmatism prior to the emplacement of granodiorites (Figure 3(a)).

The granodiorites are then cross-cut by mafic dykes (Figure 3(b)) and aplites and these are considered to be the rocks that represent the last magmatic event in the Lupa Goldfields during the Palaeoproterozoic. Contrary to the regional high metamorphic grade that has affected Ubendian rocks, the rocks in the Saza area have suffered low-grade greenschist facies metamorphism, a reminiscent of the Lake Victoria Goldfields.

The Saza area is one of the largest gold producing provinces and the Saza mine was once the second largest gold producer in Tanzania after the Geita mine during the pre-independence era [6]. Gold mineralization is associated with E-W and NW-SE trending shear zones and occurs in pyrite-bearing quartz veins. Most recently, the 


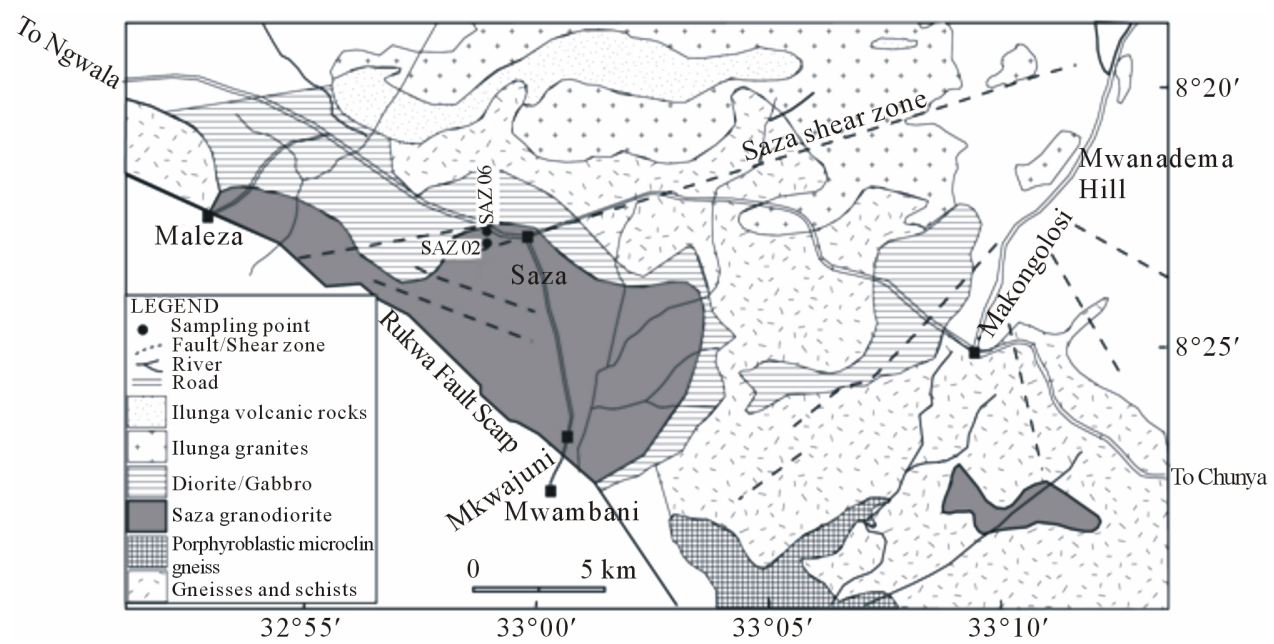

Figure 2. Geological map of the western part of the Lupa goldfield showing the location of the samples studied (after [6]).

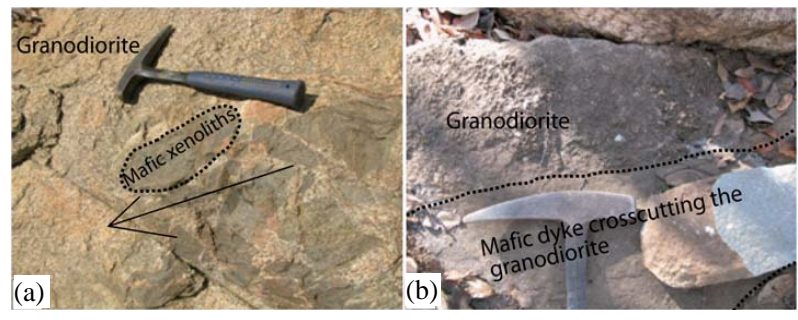

Figure 3. Photograph showing (a) the mafic xenoliths enclosed in Saza granodiorites (b) a mafic dyke cross-cutting the Saza granodiorites.
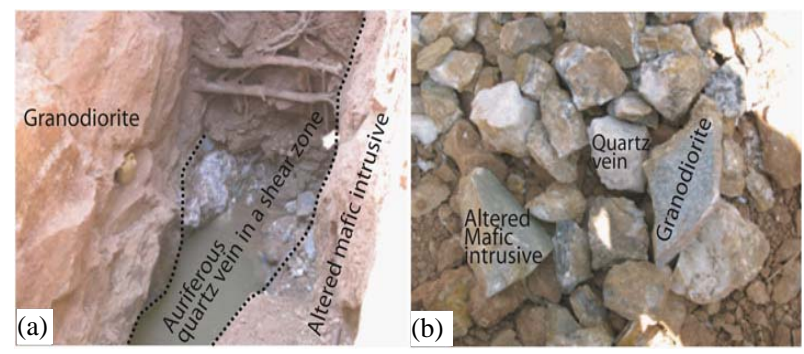

Figure 4. Photograph showing (a) auriferous quartz vein in an $\mathrm{E}-\mathrm{W}$ trending shear zone at the contact between the granodiorite and an altered mafic intrusive rock. The granodiorite sample studied was sampled from this artisanal pit as shown in (b).

ongoing exploration and research works in the LGF by Helio Resources have constrained the gold mineralizing event at 1937 Ma using Re-Os method on molybdenite [8].

\section{SAMPLES AND ANALYTICAL METHODOLOGY}

Samples used in this study were collected a few $\mathrm{km}$ nearby the former Saza mine (Figure 2). Two samples representing the granodiorites (SAZ 06) and mafic dykes cross-cutting the granodiorites (SAZ 02) were sampled and prepared for zircon U-Pb dating. SAZ 06 is a granodiorite sample that is in a sheared contact with an altered mafic intrusive rock most likely a diorite along which an auriferous quartz vein occurs (Figure 4). It is comprised of plagioclase $(40 \%)$, quartz $(35 \%)$, microcline $(10 \%)$, biotite (8\%), hornblende (5\%) and magnetite $(2 \%)$ as shown in Figure 5(a)). It is composed of $\mathrm{SiO}_{2}=63.3$ $\mathrm{wt} \%, \mathrm{MgO}=1.19 \mathrm{wt} \%$ and total alkali contents $=6.44$ wt\% (Table 1, compositions expressed on no water free basis). On the other hand, SAZ 02 is a narrow mafic dyke that was found cross-cutting the granodiorite (Figure 3(b)). It is comprised of globular masses of olivines (20\%), pyroxenes (30\%), altered plagioclase $(30 \%)$ and hornblende (20\%) as shown in Figure 5(b). It is composed of $\mathrm{SiO}_{2}=49.7 \mathrm{wt} \%, \mathrm{MgO}=5.59 \mathrm{wt} \%$ and total alkali contents $=4.44 \mathrm{wt} \%$ (Table 1).

Approximately $2 \mathrm{~kg}$ of samples SAZ 06 and SAZ 02 were crushed and powdered to $250 \mu \mathrm{m}$. A heavy mineral concentrate was obtained using heavy liquids and magnetic separation at the Activation Laboratories of Ontario, Canada. Hand-picked representative grains from the sample were mounted in epoxy resin together with chips of the TEMORA (Middledale Gabbroic Diorite, New South Wales, Australia) and 91,500 (Geostandard zircon, [9]) reference zircons and polished for imaging.

Zircon Back-Scattered Electron (BSE) and CathodoLuminiscence (CL) images were taken prior to analysis. The U-Pb analyses of the zircons were made using SHRIMP-II. The data were reduced in a manner similar to that described by Williams [10] and references therein). SQUID Excel Macro of Ludwig [11] was used. Uncertainties given for individual analyses (ratios and ages) are at the one sigma level; however the uncertainties in calculated concordia ages are reported as two sigma levels. The concordia plots and concordia age calculations have been prepared using ISOPLOT/EX [12]. 


\section{RESULTS AND DISCUSSION}

SHRIMP U-Th-Pb analytical data for zircons from the Saza granodiorite sample SAZ 06 and mafic dyke sample SAZ 02 are reported in Table 2. Zircon grains from sample SAZ 06 vary from ovoid ( $\mathrm{Zr} 1)$ to a few prismatic ones ( $\mathrm{Zr} \mathrm{3}$ ) with lengths varying from 60 to $110 \mu \mathrm{m}$ (Figure 6). On the basis of the CL images (Figure 6), zircon grains from the granodiorite sample do not show any overgrowth features and a few of them show oscillatory zoning ( $\mathrm{Zr} \mathrm{3}$ ). Twelve analyses were performed on 7

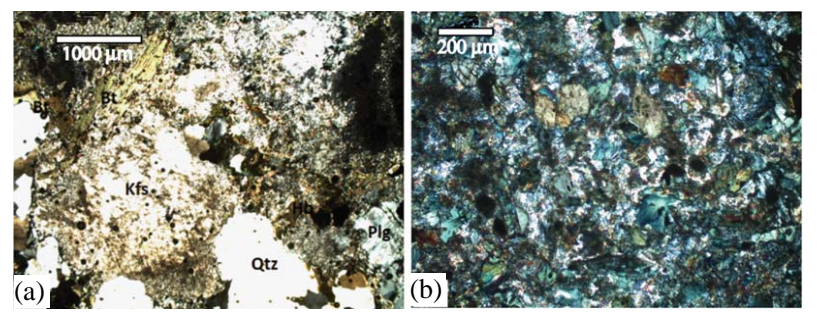

Figure 5. Thin-section for granodiorite sample SAZ 06 (a) and mafic dyke sample SAZ 02 (b) showing their mineral compositions.
Table 1. Major element composition (wt\%) of the studied samples.

\begin{tabular}{ccc}
\hline & Mafic dyke & Granodiorite \\
\hline $\mathrm{SiO}_{2}$ & $\mathrm{SAZ} 02$ & $\mathrm{SAZ} 06$ \\
$\mathrm{Al}_{2} \mathrm{O}_{3}$ & 49.7 & 63.3 \\
$\mathrm{Fe}_{2} \mathrm{O}_{3}$ & 16.9 & 16.4 \\
$\mathrm{MnO}$ & 9.89 & 3.56 \\
$\mathrm{MgO}$ & 0.15 & 0.04 \\
$\mathrm{CaO}$ & 5.59 & 1.19 \\
$\mathrm{Na} \mathrm{O}_{2}$ & 8.21 & 3.15 \\
$\mathrm{~K}_{2} \mathrm{O}$ & 3.36 & 3.78 \\
$\mathrm{TiO}_{2}$ & 1.08 & 2.66 \\
$\mathrm{P}_{2} \mathrm{O}_{5}$ & 1.50 & 0.43 \\
$\mathrm{LOI}$ & 0.21 & 0.12 \\
$\mathrm{Total}$ & 2.65 & 4.36 \\
$\mathrm{Mg}$ & 99.3 & 99.0 \\
\hline
\end{tabular}

Table 2. SHRIMP zircon U-Th-Pb analytical data for Saza intrusive rocks.

\begin{tabular}{|c|c|c|c|c|c|c|c|c|c|c|c|c|c|}
\hline Analysis ID & $\begin{array}{c}\text { Th } \\
\text { ppm }\end{array}$ & $\begin{array}{c}\mathrm{U} \\
\mathbf{p p m}\end{array}$ & $\frac{\mathbf{T h}}{\mathbf{U}}$ & $\frac{{ }^{207} \mathbf{P b}}{{ }^{235} \mathbf{U}}$ & $\pm \%$ & $\frac{{ }^{206} \mathbf{P b}}{{ }^{238} \mathbf{U}}$ & $\pm \%$ & Rho & \multicolumn{2}{|c|}{$\frac{{ }^{206} \mathbf{P b}}{{ }^{238} \mathbf{U}}$} & \multicolumn{2}{|c|}{$\frac{{ }^{207} \mathbf{P b}}{{ }^{206} \mathbf{P b}}$} & \% Discor dancy \\
\hline \multicolumn{14}{|c|}{ SAZ 02-Mafic dyke } \\
\hline 1.1 core & 496 & 448 & 1.11 & 5.36 & 1.8 & 0.3522 & 1.1 & 0.60 & 1945 & \pm 18 & 1805 & \pm 26 & -7 \\
\hline 1.2 core & 715 & 557 & 1.28 & 4.95 & 2 & 0.3284 & 0.9 & 0.47 & 1830 & \pm 15 & 1789 & \pm 32 & -2 \\
\hline 2.1central & 64 & 77 & 0.83 & 4.74 & 5.1 & 0.3173 & 1.9 & 0.37 & 1777 & \pm 29 & 1772 & \pm 87 & 0 \\
\hline 3.1 central & 38 & 85 & 0.45 & 5.26 & 3.9 & 0.3535 & 1.4 & 0.36 & 1951 & \pm 24 & 1763 & \pm 66 & -10 \\
\hline 4.1 core, zoned & 247 & 218 & 1.13 & 4.17 & 4.1 & 0.2919 & 1.4 & 0.33 & 1651 & \pm 20 & 1692 & \pm 72 & 2 \\
\hline 4.2 core, zoned & 825 & 641 & 1.29 & 5.29 & 1.3 & 0.3418 & 0.9 & 0.71 & 1895 & \pm 15 & 1836 & \pm 17 & -3 \\
\hline 5.1 core, zoned & 1166 & 789 & 1.48 & 2.33 & 3.3 & 0.1928 & 1.1 & 0.33 & 1137 & \pm 11 & 1377 & \pm 59 & 21 \\
\hline $5.2 \mathrm{rim}$ & 487 & 445 & 1.09 & 2.89 & 3.3 & 0.2262 & 1 & 0.31 & 1315 & \pm 12 & 1484 & \pm 59 & 13 \\
\hline 6.1 central, zoned & 596 & 509 & 1.17 & 5.04 & 1.9 & 0.3378 & 0.9 & 0.52 & 1876 & \pm 16 & 1771 & \pm 29 & -6 \\
\hline 7.1 central & 680 & 527 & 1.29 & 4.11 & 1.8 & 0.2892 & 0.95 & 0.53 & 1638 & \pm 14 & 1678 & \pm 28 & 2 \\
\hline \multicolumn{14}{|c|}{ SAZ 06-Saza granodiorite } \\
\hline 1.1 central, zoned & 101 & 143 & 0.70 & 5.75 & 2.1 & 0.3468 & 1.2 & 0.55 & 1919 & \pm 19 & 1960 & \pm 32 & 2 \\
\hline 1.2 outer, zoned & 95 & 201 & 0.47 & 5.02 & 5.8 & 0.3129 & 1.4 & 0.24 & 1755 & \pm 21 & 1901 & \pm 100 & 8 \\
\hline 2.1 core, zoned & 112 & 128 & 0.87 & 5.1 & 6 & 0.325 & 3.6 & 0.60 & 1816 & \pm 57 & 1858 & \pm 86 & 2 \\
\hline 3.1 central, zoned & 373 & 345 & 1.08 & 4.64 & 1.5 & 0.2975 & 0.94 & 0.62 & 1679 & \pm 14 & 1851 & \pm 21 & 10 \\
\hline 3.2 outer, zoned & 263 & 354 & 0.74 & 4.00 & 1.8 & 0.2585 & 0.86 & 0.48 & 1482 & \pm 11 & 1837 & \pm 28 & 24 \\
\hline 4.1 central & 59 & 123 & 0.48 & 5.68 & 2.6 & 0.3507 & 1.7 & 0.67 & 1938 & \pm 29 & 1918 & \pm 35 & -1 \\
\hline 5.1 core, zoned & 149 & 177 & 0.84 & 5.72 & 5.4 & 0.359 & 5.2 & 0.97 & 1979 & \pm 89 & 1887 & \pm 23 & -5 \\
\hline 5.2 outer, zoned & 175 & 256 & 0.68 & 5.60 & 3.6 & 0.3503 & 0.96 & 0.27 & 1936 & \pm 16 & 1895 & \pm 62 & -2 \\
\hline 6.1 core, zoned & 116 & 165 & 0.70 & 5.54 & 1.4 & 0.3432 & 0.96 & 0.68 & 1902 & \pm 16 & 1913 & \pm 19 & 1 \\
\hline 7.2 outer & 50 & 71 & 0.71 & 5.62 & 3 & 0.3549 & 1.4 & 0.45 & 1958 & \pm 23 & 1879 & \pm 49 & -4 \\
\hline 7.3 outer & 111 & 266 & 0.42 & 4.80 & 2.1 & 0.3011 & 0.96 & 0.46 & 1697 & \pm 14 & 1891 & \pm 34 & 11 \\
\hline
\end{tabular}


zircons of sample SAZ 06 (Table 2). When plotted on a concordia diagram (Figure 6), the regression involving all the twelve data points yielded an upper intercept age of $1903 \pm 24$ Ma and a lower intercept age of $399 \pm 250$ Ma (MSWD $=0.64$ ), all regressions employing Isoplot/ Exe of Ludwig, [11]. The upper intercept age obtained is indistinguishable from a 7-point concordia age of $1924 \pm$ $13 \mathrm{Ma}(\mathrm{MSWD}=2.6)$. On the basis of its better précission, the concordant age of $1924 \pm 13 \mathrm{Ma}$ is considered to be the magmatic age of the Saza granodiorite.

Zircon grains from SAZ 02 are prismatic showing good zircon terminals ( $\mathrm{Zr}$ 2) and a few shows zoning which is sorrounded by a structure-less rim ( $\mathrm{Zr} \mathrm{4}$, Figure 7). The zircon grains have lengths varying from 50 to $120 \mu \mathrm{m}$ (Figure 7). Ten analyses were performed on seven grains of sample SAZ 02 (Table 2). When plotted on a concordia diagram (Figure 7), the regression of the data yielded a 10-point upper intercept age $1758 \pm 33 \mathrm{Ma}$ (MSWD = 0.88).

This age is within error of the concordant age obtained on analysis $\mathrm{Zr} 2.1$ which yielded ${ }^{206} \mathrm{~Pb} /{ }^{238} \mathrm{U}$ and ${ }^{207} \mathrm{~Pb} /$ ${ }^{206} \mathrm{~Pb}$ ages of $1777 \pm 29 \mathrm{Ma}$ and $1772 \pm 87 \mathrm{Ma}$, respecttively (Table 2). The $1758 \pm 33 \mathrm{Ma}$ age is hereby interpreted as the magmatic emplacement of the mafic dykes that cross-cut the granodiorites in Saza area of Lupa
Goldfield. The $1924 \pm 13$ Ma age (MSWD = 2.6) obtained for Saza granodiorites is more or less similar to the $1936 \pm 33$ Ma (MSWD = 230) age reported by Mnali [6] for the same rocks. The poor MSWD values reported by Mnali [6] for the Saza granodiorite (and Ilunga granite) led him to propose an age bracket of 1920 - 1960 Ma for the emplacement of both types of granitoids. Thus, the $1924 \pm 13$ Ma age obtained by this study provides a better constraint for the emplacement of granitoids in Saza within the LGF. This age is within error of the reported molybdenite Re-Os age of 1937 interpreted by Mackenzie et al. [8] as dating the gold mineralization event in the LGF. The more or less similar ages of granodiorite emplacement and gold mineralization event suggest that the granodiorites could possibly be the heat source (or elsewhere in the world [13,14]. In particular, McCoy et al. [14] distinguish "plutonic-related mesothermal gold deposits" of interior Alaska from the orogenic-related deposits as those where ore fluids are derived from evolving magmas.

Such a criterion would fit in the age distributions for the granodiorite emplacement and gold mineralization in Saza area within the LGF.

The $1758 \pm 33$ Ma age obtained for the mafic dykes that cross-cut the granodiorites in Saza area is younger

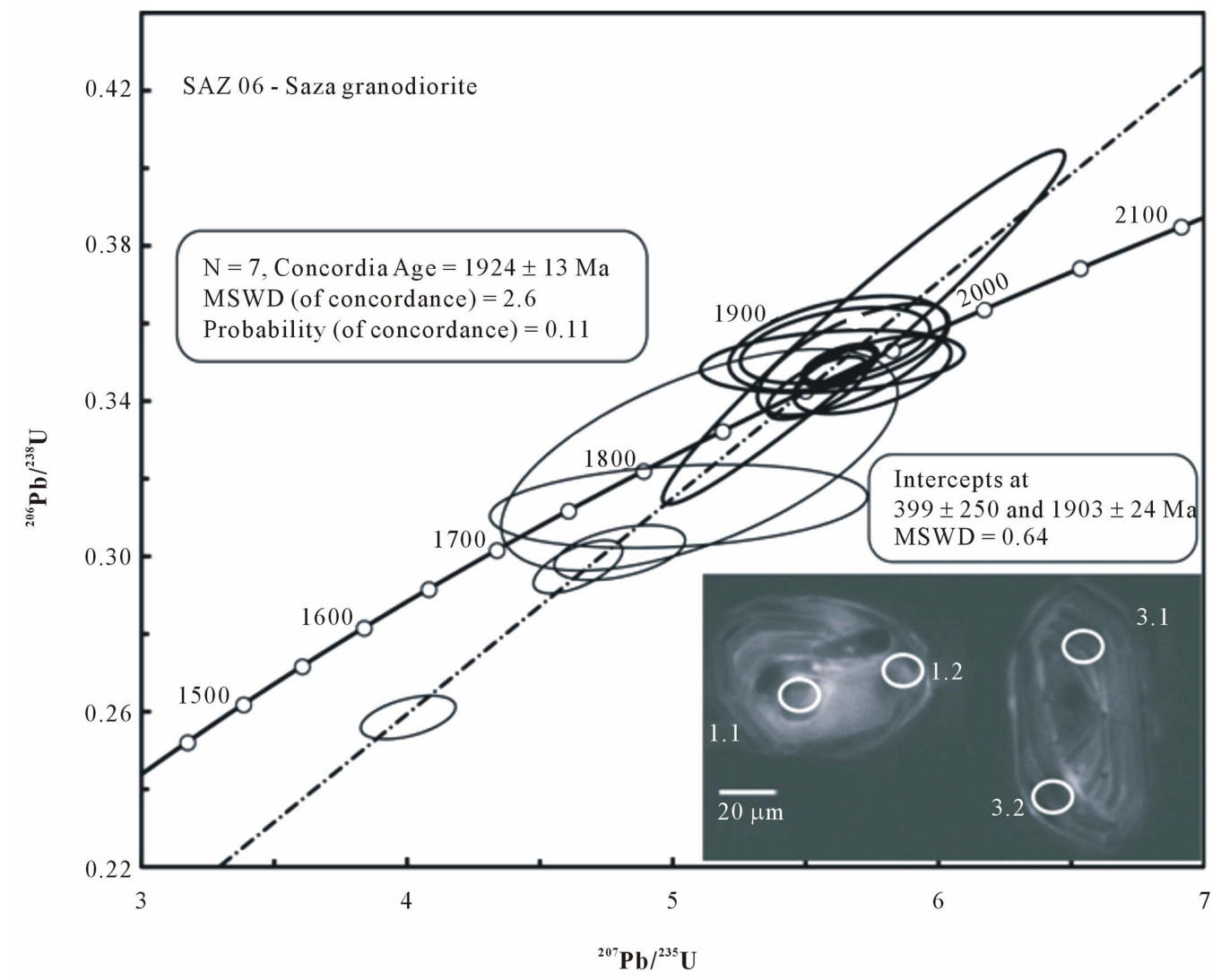

Figure 6. U-Pb Concordia diagram for the granodiorite sample SAZ 06. Zr 1 and Zr 3 represent the CL images of representative zircons showing position of analyses in Table 2. 


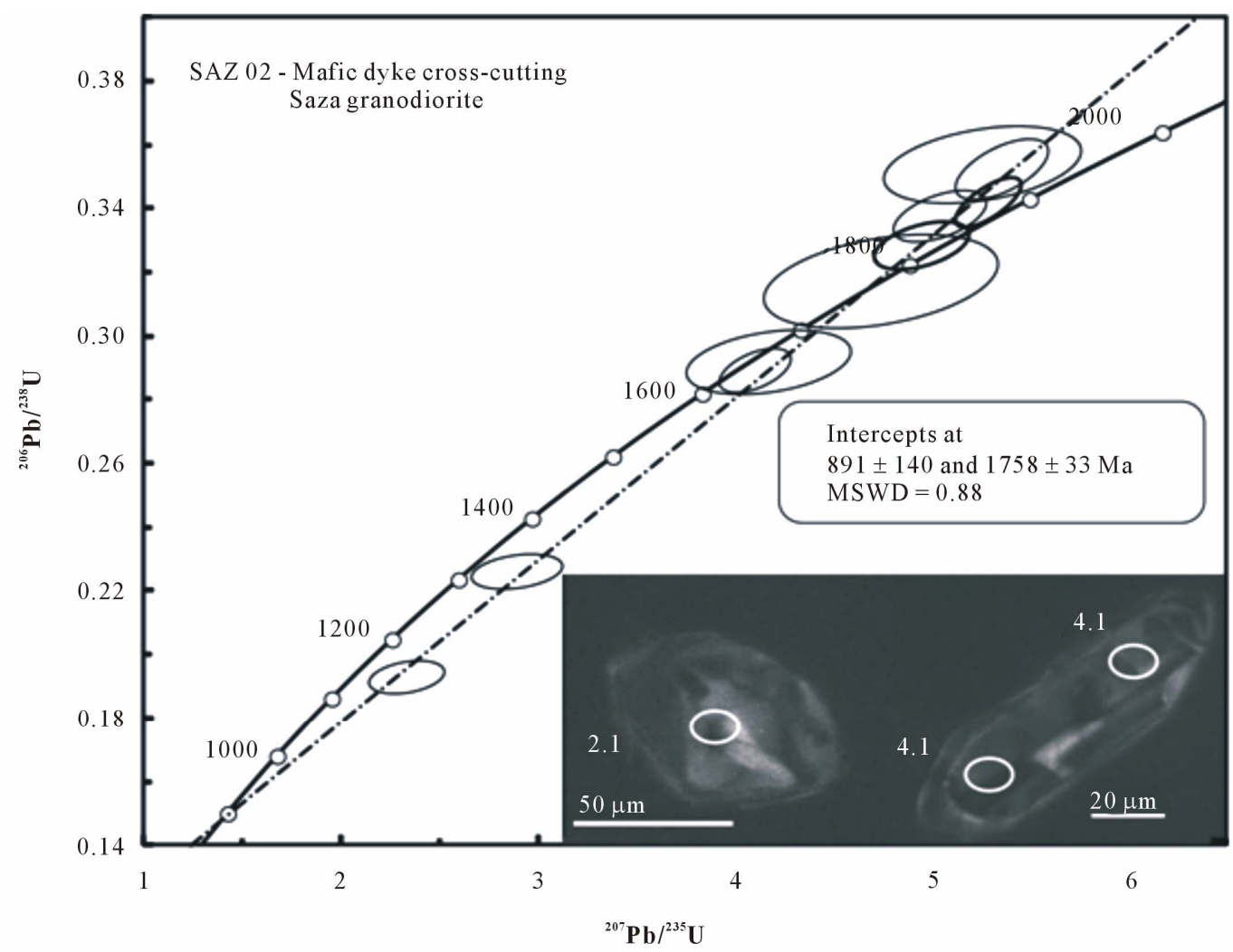

Figure 7. U-Pb Concordia diagram for the mafic dyke sample SAZ 02 that cross-cut the Saza granodiorites with CL images of representative zircons indicating position of analyses in Table 2.

than most ages reported on Ubendian granites which cluster around ages of 2.0 - $1.8 \mathrm{Ga}$ (i.e. the Mbarali granite $(2026 \pm 8 \mathrm{Ma})$, the Ufipa granite-gneiss $(1864 \pm 32$ $\mathrm{Ma})$ ) during the Palaeoproterozoic [15, 16 and references therein]. The age cluster of 2.0 - $1.8 \mathrm{Ga}$ are interpreted to represent the granulite and amphibolite facies peak metamorphic conditions in the Ubendian [15]. This indicates that the $1758 \pm 33 \mathrm{Ma}$ age of the mafic dykes represent the last magmatic event that concluded the evolution of the LGF and the entire Ubendian Belt during the Palaeoproterozoic times.

\section{ACKNOWLEDGEMENTS}

I would like to acknowledge the financial support I received from Sida through the Earth Science Programe, "Geology and Mineralization of volcanic and associated plutonic rocks of southwestern Tanzania Project” of College of Natural and Applied Sciences (CoNAS).

\section{REFERENCES}

[1] McConnell, R. (1950) Outline of the geology of Ufipa and Ubende. Geological Survey of Tanganyika Bulletin, 19, 62.

[2] Daly, M.C., Klerkx, J. and Nanyaro, J.T. (1985) Early proterozoic terranes and strike-slip accretion in the Ubendian Belt of southwest Tanzania. Terra Cognita, 5, 257.
[3] Daly, M.C. (1988) Crustal shear zones in central africa: A kinematic approach to proterozoic tectonics. Episodes, 11, 5-11.

[4] Boniface, N., Schenk, V. and Appel, P. (2012) Paleoproterozoic eclogites of MORB-type chemistry and three proterozoic orogenic cycles in the Ubendian Belt (Tanzania): Evidence from monazite and zircon geochronology, and geochemistry. Precambrian Research, 192-195, 1633.

[5] Hanson, R.E. (2003) Proterozoic geochronology and tectonic evolution of southern Africa. In proterozoic east Gondwana: Supercontinent assembly and break up. Geological Society of London, 427-463.

[6] Mnali, S.R. (1999) Palaeoproterozoic felsic magmatism and associated gold-quartz vein mineralization in western part of the Lupa Gold Field, south-western Tanzania. Ph.D. Thesis, University of Dar es Salaam, Dar es Salaam.

[7] Nanyaro, J.T. (1987) Proterozoic gold-base metal veins in the Mpanda Mineral Field, western Tanzania. Ph.D. Thesis, University of Dar es salaam, Dar es Salaam.

[8] McKenzie, C., Sheets, R., Moore, J. and Selby, D. (2009) Ubendian mineralization in the Lupa Goldfields, southwestern Tanzania: New discoveries and geochronology. http://www.helioresource.com/i/pdf/Gold\%20Mineralisati on\%20in\%20the\%20Lupa\%20Goldfields.pdf

[9] Wiedenbeck, M., Alle, P., Corfu, F., Griffin, W.L., Meier, M., Oberli, F., von Quadt, A., Roddick, J.C. and Spiegel, 
W. (1995) Three natural zircon standards for U-Th-Pb, Lu-Hf, trace element and REE analyses. Geostandards Newsletter, 19, 1-23. doi:10.1111/j.1751-908X.1995.tb00147.x

[10] Williams, I. (1998) U-Th-Pb Geochronology by Ion Microprobe. Application of microanalytical techniques to understanding mineralizing processes, vol. 7. In: McKibben, M., Shanks, W.J. and Ridley, W., Eds., Reviews in Economic Geology, The Society, Toronto, 1-35.

[11] Ludwig, K.R. (1999) User's manual for Isoplot/Ex, version 2.10, a geochronological toolkit for microsoft excel. Berkeley Geochronology Center Special Publication, Berkeley.

[12] Ludwig, K.R. (2000) SQUID 1.00, a user's manual. Berkeley Geochronology Center Special Publication, Berkeley.

[13] Sillitoe, R.H. (1991) Intrusion-related gold deposits. In: Foster, R.P., Ed., Gold metallogeny and exploration.
Blackie and Son Ltd., Glassgow, 165-209.

[14] McCoy, D., Newberry, R.J., Layer, P., DiMarchi, J.J., Bakke, A., Masrerman, J.S. and Minehand, D.L. (1997) Plutonic-related gold deposits of interior Alaska. In: Goldfarb, R.J. and Miller, L.D., Eds., Economic geology monogram, Economic Geology Publishing Company, El Paso, 9. doi:10.2113/gsecongeo.86.6.1187

[15] Lenoir, J.L., Liegeois, J.P., Theunissen, K. and Klerkx, J. (1994) The palaeoproterozoic Ubendian shear belt in Tanzania: Geochronology and structure. Journal of African Earth Sciences, 19, 169-184. doi:10.1016/0899-5362(94)90059-0

[16] Boven, A., Theunissen, K., Sklyarov, E., Klerkx, J., Melnikov, A., Mruma, A. and Punzalan, L. (1999). Timing of exhumation of a high-pressure mafic granulite terrane of the paleoproterozoic Ubende Belt (west Tanzania). Precambrian Research, 93, 119-137. doi:10.1016/S0301-9268(98)00101-6 